\title{
Image Scrambling Using non Sinusoidal Transforms and key Based Scrambling Technique
}

\author{
H.B.Kekre, Tanuja Sarode, Pallavi Halarnkar,Debkanya Mazumder \\ Sr. Professor, MPSTME, Mumbai \\ hbkekre@yahoo.com \\ Associate Professor, TSEC, Mumbai \\ Tanuja0123@yahoo.com \\ PhD Research Scholar, MPSTME, Mumbai \\ Pallavi.halarnkar@gmail.com \\ Student, MPSTME, Mumbai \\ Rimjhim.mazumder17@gmail.com
}

\section{ABSTRACT}

Nowadays Digital Images find a lot of applications almost in all the fields, for e.g. Information Hiding. Security of these images is very important. Image encryption is one method of providing security to digital images. In this paper we have proposed a method for Image scrambling which is based on a combination of spatial and frequency domain. Four different Non sinusoidal transforms, Walsh, Slant ,Kekre and Haar were used. Three different types i.e Row , Column and Full Transforms of these four transforms were applied for Image scrambling, out of these four Kekre Transform gave the best result

\section{Indexing terms/Keywords}

Scrambling; Encryption; Walsh Transform; Slant Transform; Kekre Transform and Haar Transform.

\section{Academic Discipline And Sub-Disciplines}

Computer Science and Engineering

\section{SUBJECT CLASSIFICATION}

Image Processing and Analysis

\section{TYPE (METHOD/APPROACH)}

Experimental Analsyis

\section{Council for Innovative Research}

Peer Review Research Publishing System

Journal: INTERNATIONAL JOURNAL OF COMPUTERS \& TECHNOLOGY

Vol 12 , No. 8

editor@cirworld.com

www.cirworld.com, www.ijctonline.com 


\section{INTRODUCTION}

With the widespread of Digital Image data, over internet it has become very important to provide security to these digital images. One of the method used is Image encryption so that they can be transmitted across network without the attacker been able to see the actual content of it as it is encrypted. There are a lot of methods presented in literature for this purpose. Providing an Image scrambling technique should not only be in spatial domain but should also include transform domain , as we know Transform domain is much robust then the spatial domain to many factors for e.g. noise. In this paper we have presented a method which combines both spatial as well as frequency domain. An encryption technique based on pixels is proposed in[1]. Firstly the image is scrambled using the method of watermarking making it difficult for decoding purpose. Lastly a camouflaged image to vision or the pixels of the true image to get the final encrypted image. The key parameters are encrypted using Elliptic curve cryptography (ECC). The algorithm security, reliability and efficiency is analyzed via experimental analysis. Image security has a wide number of applications specially when some information is to be hidden into a digital image and must be protected from unauthorized access to it. Encryption of Digital images makes security of it possible. As encryption and decryption of digital images consumes lot of time, in [2] considering time as one of the important factor, encryption process is applied over to selected regions in the image, which provides the facility for selective encryption and selective reconstruction of images. The proposed method is compared with traditional methods. The efficiency and advantages of the proposed method over conventional method are discussed.

In [3], firstly textual message is encrypted using a suitable key, to obtain some suitable nonlinear pixel and bit positions about the entire image. As a result, a watermarked image is obtained. Three different image shares are obtained by combining any two components R, G or B of the watermarked image. The key is also divided into three different logical blocks by digits. The key shares are assigned to image shares. Out of the three shares only a combination of two shares will result in the full image or key. At the decryption side , appropriate arrangement of shares of key and image makes the retrieval of hidden data

[4] proposed a novel encryption method called as Bit Recirculation Image Encryption(BRIE). The paper points out that BRIE is not secured enough from attacks. Some defects exists in BRIE, and a know/chosen plaintext attack can break BRIE. Experiments are made to verify the defects and the feasibility of the attack. Security is very important in transmission of digital images and video conferencing. There is a huge increase in the use of digital images in industrial process, security of these images with confidential data from unauthorized access is very important. Advanced encryption standard(AES) is a well known block cipher method, however it is not suitable fro real time applications. In [5] , a modification to AES is been proposed to provide a high level of security and better image encryption. Modification to the method is done by shift row transformation. Experimental results of security analysis are given. The proposed method is highly secured from cryptographic viewpoint. The method is also robust against statistical attacks. A logistic based image encryption techniques is been proposed in [6]. A Haar wavelet is applied over the image to decompose it and decorrelate its pixels into averaging and differencing components. The method produces cipher of the digital image that has good confusion and diffusion properties. The differencing components are compressed using a wavelet transform. Key transmission is done using steganography concept. Tests like NPCR, UACI and PSNR are carried out for experimental analysis.An upgraded method of SD-EI is proposed in [7] called as SD-AEI. The method has three stages. Firstly each pixel is converted to its binary equivalent, In eight bit number, the number of bits equivalent to the length of the password is rotated and reversed. In the second stage extended, hill cipher technique is applied by using evolutionary matrix which is generated by using the same password. In the last stage the whole image is randomized using Modified MSA Randomization encryption technique. The proposed technique is very effective in encrypting any type of image. Experimental results show that the proposed method takes optimal amount of time compared to other traditional techniques. A new invertible two dimensional map is proposed in [8] called as Line Map, for image encryption and decryption. The method maps the digital image to an array of pixels and then maps it back from array to image. A Line Map consists of two maps, a left map and a right map. The drawback of the traditional 2D maps which can be used only for permutation is overcome by Line Map which can perform two processes of image encryption, permutation and substitution simultaneously using the same maps. The proposed method does not have a loss of information, it is also fast and there is no restriction on the length of the security key. An image encryption algorithm based on DNA sequences for Big Images is presented in [9]. The main aim of the method is to reduce the time required to encrypt big images. The method uses natural DNA sequences as keys. Firstly the pixels of the image are scrambled, then the image is confused in the light of scrambling sequence generated by the DNA sequence. Second part involves the process of pixel replacement. The pixel gray values of the new image and the one of the three encryption templates are generated by the other DNA sequence are XORed bit by bit in turn. Experimental results show that the method is feasible and simple.

An image encryption scheme based on JPEG compression tolerant is proposed in [10]. The two main features of the proposed scheme are the decryption algorithm is able to reconstruct the original image even if the encrypted image is JPEG compressed. Secondly the encryption algorithm can be adjusted to produce cipher image with varying perceptual distortion. The proposed method has an advantage that the encrypted image can be compressed and then transmitted across the network thus saving the bandwidth. The proposed method can be used for low level encryption in which the cipher image has a degraded visual quality but reflects the contents of the plain text-image or high level encryption in which the cipher image does not reveal any information about the plain -text image. 


\section{NON SINUSOIDAL TRANSFORM}

1) Walsh Transform [11]

Walsh transform matrix is defined as a set of $\mathrm{N}$ rows, denoted by $\mathrm{Wj}$, for $\mathrm{j}=0,1, \ldots, \mathrm{N}-1$, which have the following properties

i. $\quad$ Wj takes on the values +1 and -1 .

ii. $\quad W j[0]=1$ for all $j$.

iii. $\quad W j \times W k^{t}=0$ for $j \neq k$ and $W j \times W k^{t}=N$, for $j=k$.

iv. Wj has exactly $\mathrm{j}$ zero crossings, for $\mathrm{j}=0,1, \ldots, \mathrm{N}-1$.

v. Each row $\mathrm{Wj}$ is either even or odd with respect to its midpoint.

Walsh transform matrix is generated using a Hadamard matrix of order $\mathrm{N}$. The Walsh transform matrix row is the row of the Hadamard matrix specified by the Walsh code index, which must be an integer in the range [0... N - 1]. For the Walsh code index equal to an integer $\mathrm{j}$, the respective Hadamard output code has exactly $\mathrm{j}$ zero crossings, for $\mathrm{j}=0,1, \ldots, \mathrm{N}-1$.

\section{2) Slant Transform[12]}

The slant transform has its first basis function as constant and second basis function as linear. The Slant vector is a discrete saw tooth waveform decreasing in uniform steps over its length. It is been seen that Slant vectors are suitable for efficiently representing gradual brightness change in an image line. E.g. Television.

\section{Slant Matrix Construction}

If $\mathrm{S}(\mathrm{n})$ denotes the $\mathrm{N} x \mathrm{~N}$ Slant matrix $\left(\mathrm{N}=2^{\mathrm{n}}\right)$, then

$$
S(1)=\frac{1}{\sqrt{2}}\left[\begin{array}{cc}
1 & 1 \\
1 & -1
\end{array}\right]
$$

The Slant matrix for $\mathrm{N}=4$ can be written as

$$
\mathrm{S}(2)=\frac{1}{\sqrt{4}}\left[\begin{array}{cccc}
1 & 1 & 1 & 1 \\
a+b & a-b & -a+b & -a-b \\
1 & -1 & -1 & 1 \\
a-b & -a-b & a+b & -a+b
\end{array}\right]
$$

where $\mathrm{a}$ and $\mathrm{b}$ are real constants to be determined subject to the following conditions:

(i) Step size must be uniform

(ii) $\quad \mathrm{S}(2)$ must be orthogonal

The properties of Slant transform are as follows:

i. The Slant transform is real and orthogonal

$$
S=S^{*}, S^{-1}=S^{t}
$$

ii. It has fast algorithm which is of order

$$
\mathrm{O}\left(\mathrm{N} \log _{2} \mathrm{~N}\right) \text { for } \mathrm{NX} 1 \text { vector }
$$

iii. It is very good in energy compaction for television pictures.

3) Kekre Transform [13]

The Kekre transform matrix of dimension NXN is given below:

$$
K(x, y)=\left[\begin{array}{cccccc}
1 & 1 & 1 & 1 & 1 & 1 \\
-N+1 & 1 & 1 & 1 & 1 & 1 \\
0 & -N+2 & 1 & \cdots & 1 & 1 \\
\vdots & \vdots & \vdots & \cdots & \vdots & \vdots \\
0 & 0 & 0 & \cdots & 1 & 1 \\
0 & 0 & 0 & \cdots & -N+(N-1) & 1
\end{array}\right]
$$


The formula for generating the element $\mathrm{K}(\mathrm{x}, \mathrm{y})$ of Kekre transform matrix is given in the equation below:

$$
K(x, y)=\left\{\begin{array}{cl}
1, & x \leq y \\
-N+(x-1), & x=y+1 \\
0, & x>y+1
\end{array}\right.
$$

The properties of Kekre Transform are as follows:

i. The Kekre transform is real and orthogonal transform.

$$
[\mathrm{K}][\mathrm{K}]^{\mathrm{t}}=[\mu]
$$

Where $[\mathrm{K}]^{\mathrm{t}}$ is transpose of $[\mathrm{K}]$ and $[\mu]$ is a diagonal matrix and its elements are given by

$$
\begin{aligned}
& \mu_{11}=\mathrm{N} \\
& \mu_{\mathrm{ii}}=(\mathrm{N}-\mathrm{i})(\mathrm{N}-\mathrm{i}+1)
\end{aligned}
$$

ii. It has a fast algorithm as it contains $\mathrm{N}(\mathrm{N}+1) / 2$ number of ones and $(\mathrm{N}-1)(\mathrm{N}-2) / 2$ number of zeros leaving only $(\mathrm{N}-1)$ integer multiplications and only $(\mathrm{N}-1)(\mathrm{N} / 2)$ additions for transforming a column vector of dimension $\mathrm{N} x 1$. For a normal matrix transformation we require $\mathrm{N}^{2}$ multiplications and $\mathrm{N}(\mathrm{N}-1)$ additions.

iii. The transform of a vector $\mathbf{f}$ is given by

$$
F=[K] f
$$

and inverse is given by

$$
f=[K]^{t}[\mu]^{-1} F
$$

iv. For image [f] the transform $[F]$ is calculated as

$$
[\mathrm{F}]=[\mathrm{K}][\mathrm{f}][\mathrm{K}]^{\mathrm{t}}
$$

and inverse transform is given by

$$
[\mathrm{f}]=[\mathrm{K}]^{\mathrm{t}}\left[\mathrm{F}_{\mathrm{ij}} / \mu_{\mathrm{ij}}\right][\mathrm{K}]
$$

Where $\mu_{\mathrm{ij}}=\mu_{\mathrm{ii}} \mu_{\mathrm{ij}}$

\section{4) Haar Transform [14]}

The Haar wavelet is also the simplest possible wavelet. The technical disadvantage of the Haar wavelet is that it is not continuous, and therefore not differentiable. This property can, however, be an advantage for the analysis of signals with sudden transitions, such as monitoring of tool failure in machines.

The Haar Wavelets mother wavelet function $\varphi(t)$ can be described as

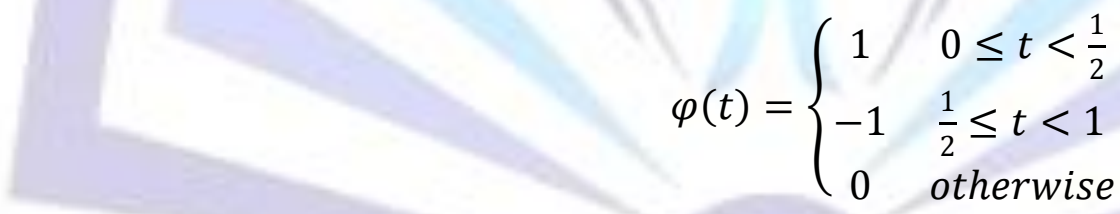

and its scaling function $\varphi(t)$ can be defined

$$
\varphi(t)=\left\{\begin{array}{cc}
1 & 0 \leq t<1 \\
0 & \text { otherwise }
\end{array}\right.
$$

\section{PROPOSED APPROACH}

In this paper, we have proposed a novel approach in Transform Domain for Image scrambling. The proposed method makes use of four Non-Sinusoidal Transforms they are Walsh Transform, Slant Transform, Kekre Transform and Haar Transform. For transforming the image from Spatial Domain to Frequency Domain, Row, Column and full Transforms were applied over the image. The Step by Step procedure for Scrambling and De-Scrambling is explained in the section below. For scrambling the image, Key Based Scrambling[15] is used which is a Random numbers generation algorithm using the size of the image as an input. The proposed approach is based on the concept that, if any alterations are done to the transform coefficients, application of inverse transform will surely not result in the original image but a scrambled image. The proposed approach is not limited to a particular scrambling method or a transform, the said approach can make use of any scrambling technique or transform on the image. 


\section{Image Scrambling}

Following are the steps used for Image Scrambling

1) Read the image, convert it to grayscale

2) Apply a Transform on the image

3) Transform coefficients which are obtained in step 2 are now scrambled using key based scrambling method.

4) Apply inverse transform on the scrambled transform coefficients obtained in step 3.

5) The image obtained in spatial domain will now be scrambled

The scrambling process is also shown in the Figure 1.
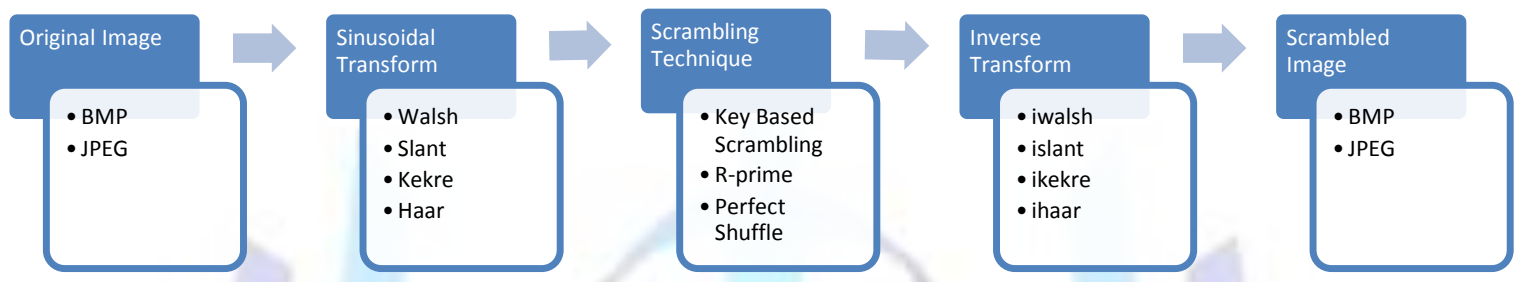

FIG 1: This Different Steps of Scrambling Process

\section{Image Descrambling}

The descrambling process is as follows

1) Read the scrambled image

2) Apply the Transform on the image

3) Transform coefficients which are obtained in step 2 are now descrambled using key based descrambling method.

4) Apply inverse transform on the descrambled transform coefficients obtained in step 3.

5) The image obtained in spatial domain will now be original Image

The descrambling process is also shown in the figure

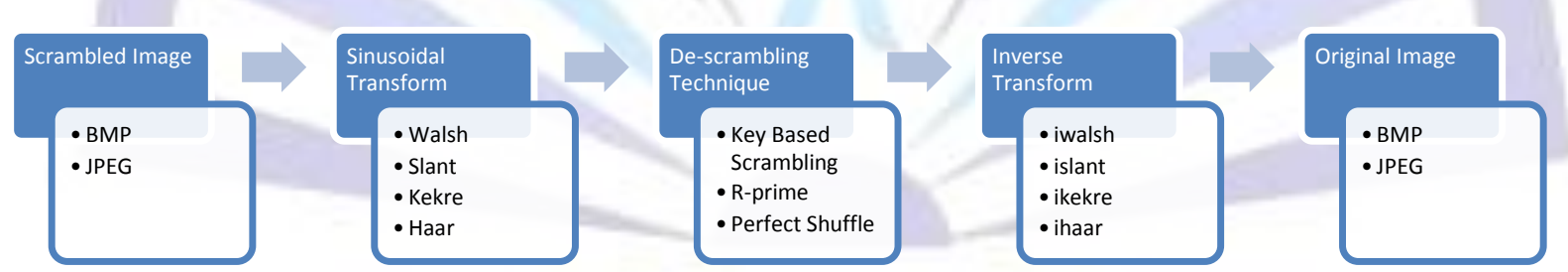

FIG 2: This Different Steps of De-Scrambling Process

\section{EXPERIMENTAL RESULTS}

For Experimental purpose, five images of size 256X256 were used with all the four Non Sinusoidal Transforms. Figure 3 (a) shows the Original Image which is a 24-bit color image which is first converted to grayscale as shown in Figure 3(b), Although the proposed method can also be extended on 24-bit color images. 


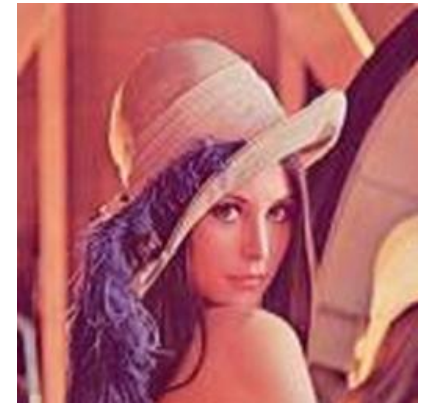

a) Original Image

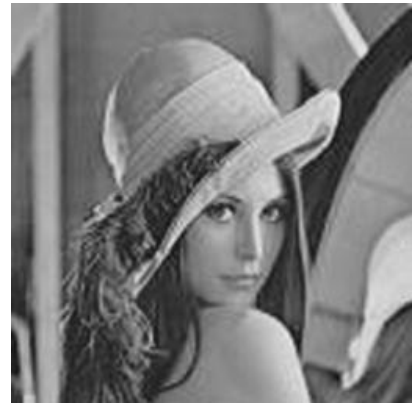

(b) Gray Image

FIG 3:

The experimental results shown below are as follows. Figure 4(a-c) shows the scrambled images obtained for walsh row,column and full transform. Figure 4(d-f) shows the descrambled images obtained for walsh row, column and full transform. Similarly Figure 5(a-c) shows the scrambled images obtained for slant row,column and full transform, Figure 5(d-e) shows the descrambled images obtained for slant row, column and full Transform. Figure 6(a-c) shows the scrambled images obtained for kekre row,column and full transform, Figure 6(d-e) shows the descrambled images obtained for kekre row, column and full Transform. Figure $7(\mathrm{a}-\mathrm{c})$ shows the scrambled images obtained for Haar row,column and full transform, Figure $7(d-e)$ shows the descrambled images obtained for Haar row, column and full Transform.

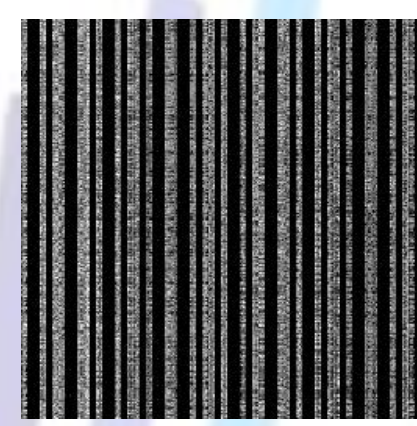

(a)Walsh Row Transform

Scrambled

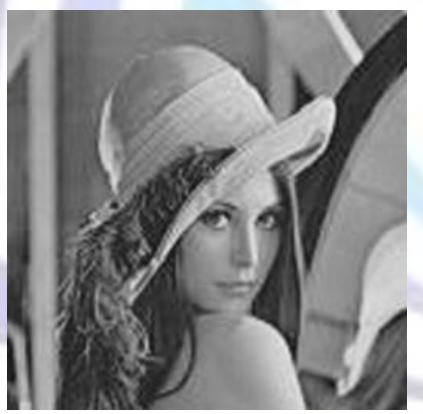

(d) Walsh Row Transform

Descrambled

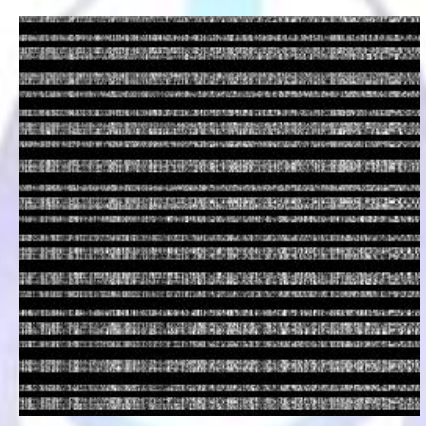

(b)Walsh Column Transform Scrambled

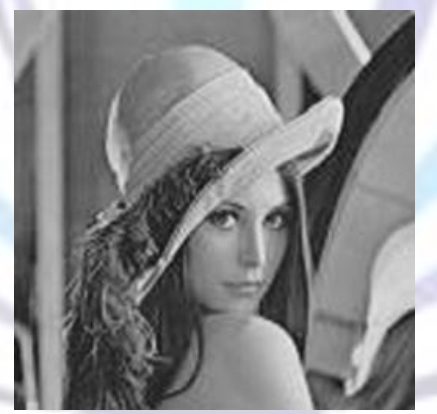

(e) Walsh Col Transform

Descrambled

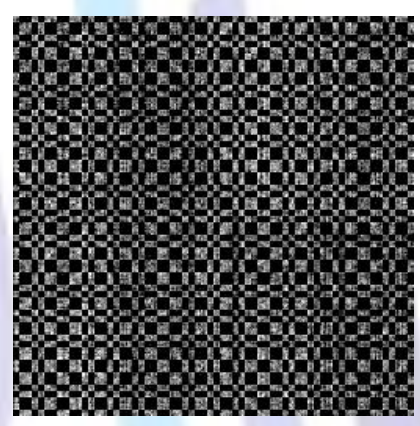

(c)Walsh Full Transform

Scrambled

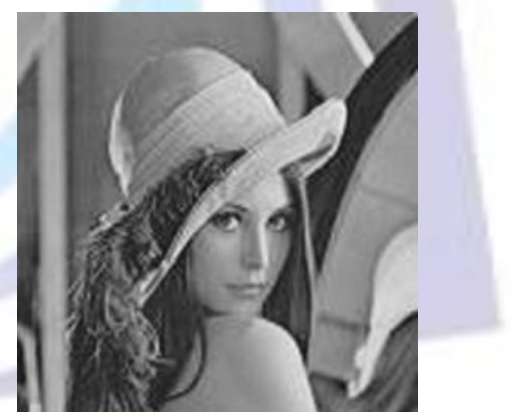

(f) Walsh Full Transform

Descrambled

FIG 4 


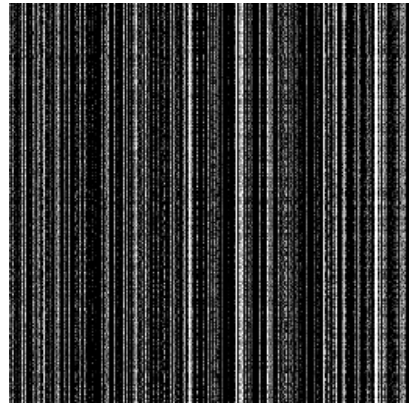

(a)slant Row Transform

Scrambled

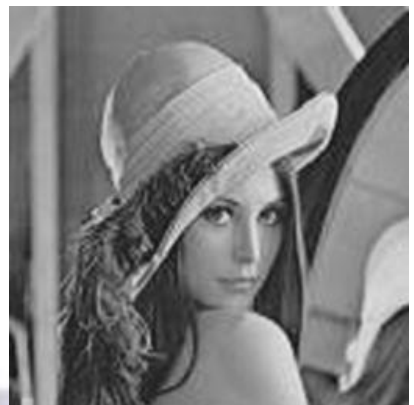

(d) slant Row Transform

Descrambled

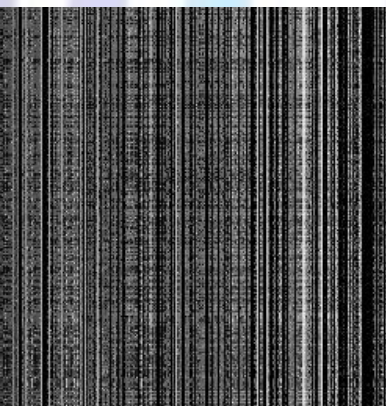

(a)kekre Row Transform Scrambled

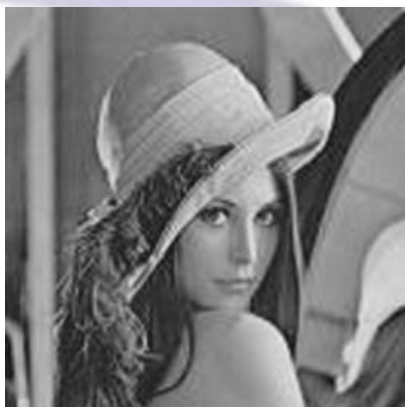

(d)kekre Row Transform

DeScrambled

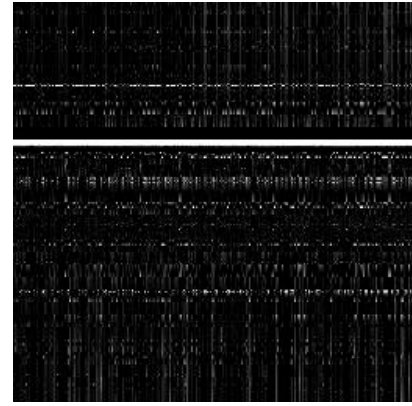

(b) slant Column Transform Scrambled

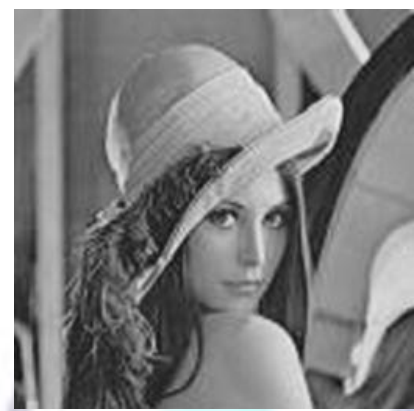

(e) slant Col Transform Descrambled FIG 5.

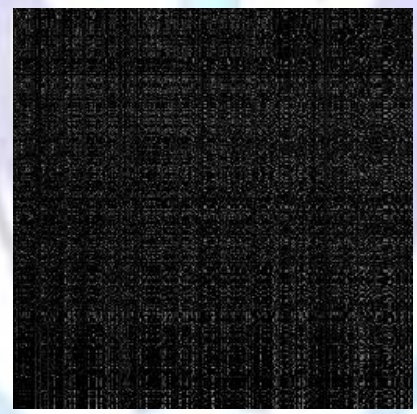

(b) kekre Column Transform Scrambled

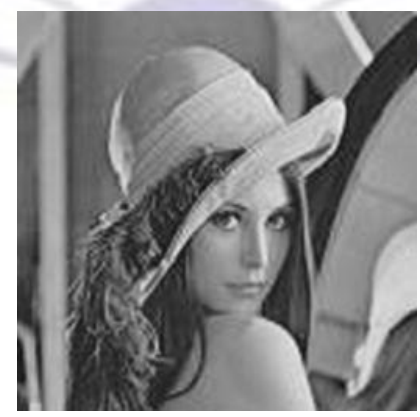

(e) kekre Column Transform DeScrambled FIG 6

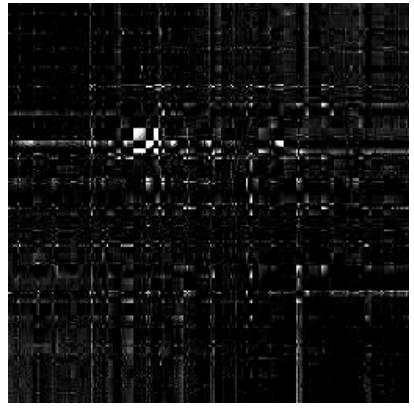

(c) slant Full Transform Scrambled

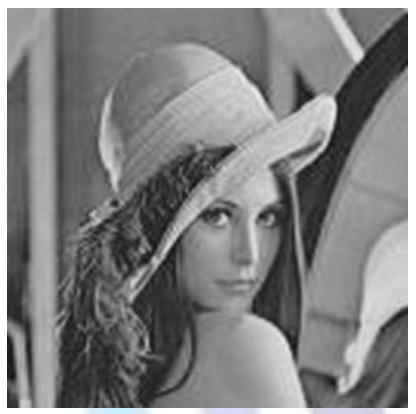

(f) slant Full Transform Descrambled

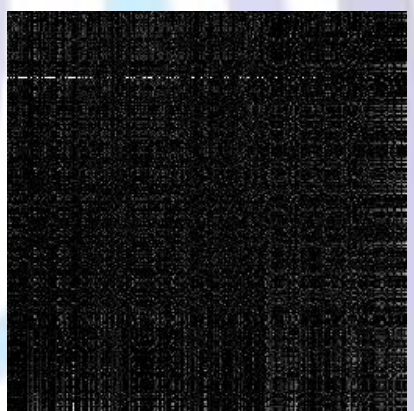

(c) kekre Full Transform Scrambled

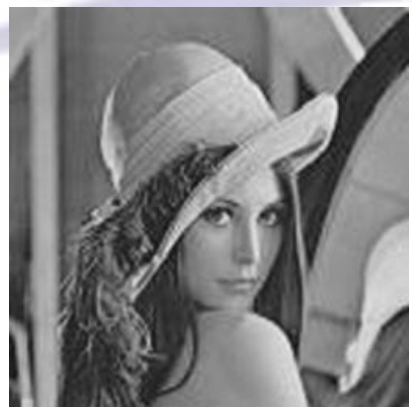

(f) kekre Full Transform DeScrambled 


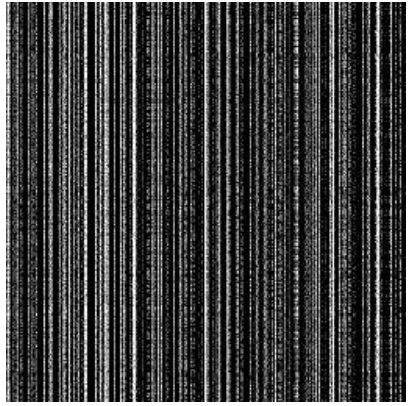

(a)Haar Row Transform

Scrambled

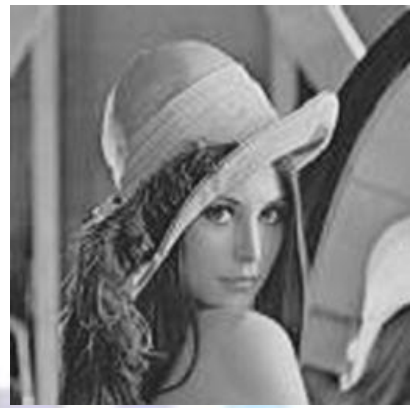

(d)Haar Row Transform

DeScrambled
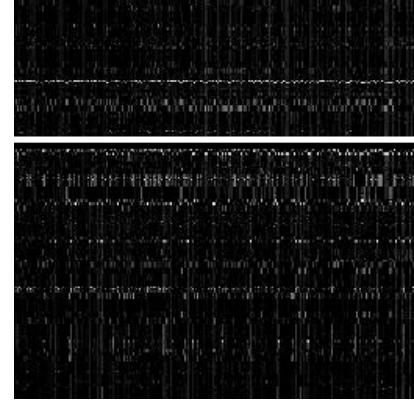

(b) Haar Column Transform

Scrambled

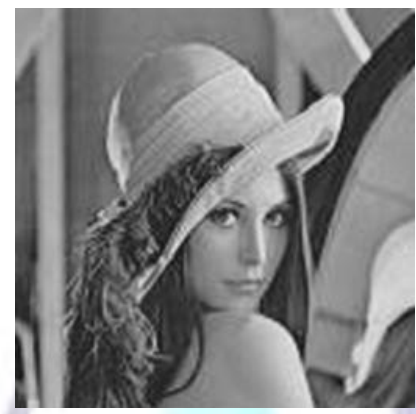

(e) Haar Column Transform

\section{DeScrambled}

FIG 7

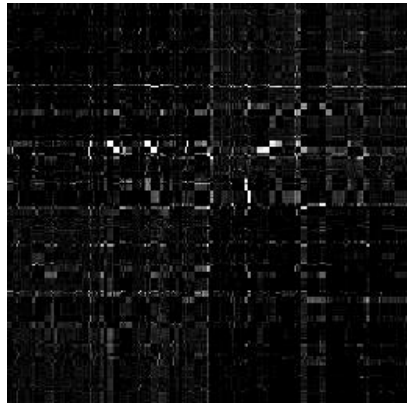

(c) Haar Full Transform

Scrambled

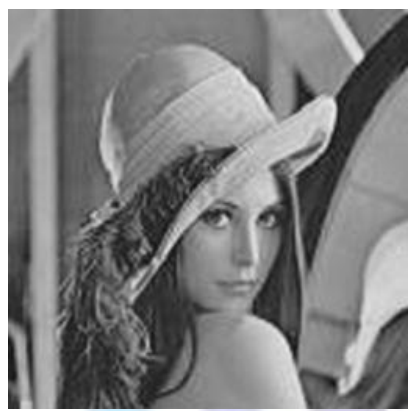

(f) Haar Full Transform

DeScrambled

\section{Observations}

As can be seen from the figures $4(a-c), 5(a-c), 6(a-c)$ and $7(a-c)$, the proposed method gives a good scrambling effect on the original image for all the four Non Sinusoidal Transforms. For evaluation of all the Transforms two parameters are been used, Average correlation between rows and columns in the original image and the scrambled image obtained by applying row transform, column transform and full transform. The second parameter used is the energy distribution in original image, row ,column and full transform image coefficients and scrambled images obtained by row, column, full transform in spatial domain.

The reason behind choosing these two parameters for experimental analysis is that, $\mathrm{A}$ image in spatial domain is highly correlated due to which a human eye can perceive the details of the image, when a transform is applied over a image it de-correlates the pixels. The aim in Image scrambling is to reduce the correlation between the pixels to make it unreadable. The proposed method is a combination of both spatial as frequency domain. As can be seen from Table No 1, slant row transform gives a reduction in correlation in Lena, pepper and cartoon images, Row Haar transform gives a reduced correlation in pepper image, whereas kekre row, column and full transform gives a reduction in correlation in all the five images tested.

The energy distribution in Original Image, Row, column and full transform image coefficients and row, column and full transform images are shown in Figure 8 to Figure 11. 
TABLE 1: Average Row and Average Column correlation obtained in Row Transform, Row Transform scrambled, Column Transform , Column Transform Scrambled , Full Transform and Full Transform scrambled images for Walsh, Slant, Kekre and Haar Transforms

\begin{tabular}{|c|c|c|c|c|c|c|}
\hline & \multicolumn{4}{|c|}{ Original Image : Lena Row: 0.8439} & \multicolumn{2}{|l|}{ Col:0.6937 } \\
\hline $\begin{array}{c}\text { Transfo } \\
\text { rms }\end{array}$ & $\begin{array}{c}\text { Row } \\
\text { Transform }\end{array}$ & $\begin{array}{c}\text { Row } \\
\text { Transform } \\
\text { Scrambled }\end{array}$ & $\begin{array}{c}\text { Column } \\
\text { Transform }\end{array}$ & $\begin{array}{c}\text { Column } \\
\text { Transform } \\
\text { Scrambled }\end{array}$ & $\begin{array}{c}\text { Full } \\
\text { Transform }\end{array}$ & $\begin{array}{c}\text { Full } \\
\text { Transform } \\
\text { Scrambled }\end{array}$ \\
\hline Walsh & $\begin{array}{c}\text { Row: } \\
0.9947 \\
\text { Col:0.2088 }\end{array}$ & $\begin{array}{l}\text { Row: } 0.3520 \\
\text { Col:0.3283 }\end{array}$ & $\begin{array}{c}\text { Row: } 0.1938 \\
\text { Col:0.9928 }\end{array}$ & $\begin{array}{c}\text { Row: } 0.4249 \\
\text { Col:0.3380 }\end{array}$ & $\begin{array}{c}\text { Row: } 0.2026 \\
\text { Col: } 0.2351\end{array}$ & $\begin{array}{c}\text { Row: } \\
0.4692 \\
\text { Col:0.3829 }\end{array}$ \\
\hline Slant & $\begin{array}{c}\text { Row:0.891 } \\
6 \\
\text { Col: } 0.3899\end{array}$ & $\begin{array}{c}\text { Row: } 0.8429 \\
\text { Col:0.2065 }\end{array}$ & $\begin{array}{c}\text { Row: } 0.3303 \\
\text { Col: } 0.9931\end{array}$ & $\begin{array}{c}\text { Row: } 0.6336 \\
\text { Col:0.8118 }\end{array}$ & $\begin{array}{c}\text { Row: } 0.4060 \\
\text { Col:0.4289 }\end{array}$ & $\begin{array}{c}\text { Row: } \\
0.6272 \\
\text { Col:0.5867 }\end{array}$ \\
\hline Kekre & $\begin{array}{c}\text { Row: } \\
0.9924 \\
\text { Col:0.7046 }\end{array}$ & $\begin{array}{c}\text { Row: } 0.8102 \\
\text { Col:0.2284 }\end{array}$ & $\begin{array}{c}\text { Row: } 0.7884 \\
\text { Col:0.9924 }\end{array}$ & $\begin{array}{c}\text { Row: } 0.2517 \\
\text { Col:0.9359 }\end{array}$ & $\begin{array}{c}\text { Row: } 0.8944 \\
\text { Col:0.8831 }\end{array}$ & $\begin{array}{c}\text { Row: } \\
0.2515 \\
\text { Col:0.2848 }\end{array}$ \\
\hline Haar & $\begin{array}{c}\text { Row: } \\
0.9122 \\
\text { Col:0.1969 }\end{array}$ & $\begin{array}{c}\text { Row: } 0.8345 \\
\text { Col:0.2048 }\end{array}$ & $\begin{array}{c}\text { Row: } 0.2382 \\
\text { Col:0.9928 }\end{array}$ & $\begin{array}{c}\text { Row: } 0.6088 \\
\text { Col:0.6960 }\end{array}$ & $\begin{array}{c}\text { Row: } 0.2466 \\
\text { Col: } 0.2794\end{array}$ & $\begin{array}{c}\text { Row: } \\
0.5935 \\
\text { Col:0.5548 }\end{array}$ \\
\hline
\end{tabular}

\begin{tabular}{|c|c|c|c|c|c|c|}
\hline & \multicolumn{4}{|c|}{ Original Image : Pepper Row: 0.8891} & \multicolumn{2}{|c|}{ Col: 0.8468} \\
\hline $\begin{array}{c}\text { Transfor } \\
\text { ms }\end{array}$ & $\begin{array}{c}\text { Row } \\
\text { Transform }\end{array}$ & $\begin{array}{c}\text { Row } \\
\text { Transform } \\
\text { Scrambled }\end{array}$ & $\begin{array}{l}\text { Column } \\
\text { Transform }\end{array}$ & $\begin{array}{l}\text { Column } \\
\text { Transform } \\
\text { Scrambled }\end{array}$ & $\begin{array}{c}\text { Full } \\
\text { Transform }\end{array}$ & $\begin{array}{c}\text { Full } \\
\text { Transform } \\
\text { Scrambled }\end{array}$ \\
\hline Walsh & $\begin{array}{c}\text { Row: } \\
0.9940 \\
\text { Col: } 0.1990\end{array}$ & $\begin{array}{c}\text { Row: } \\
0.3498 \\
\text { Col:0.3344 }\end{array}$ & $\begin{array}{c}\text { Row: } \\
0.1965 \\
\text { Col: } 0.9929\end{array}$ & $\begin{array}{l}\text { Row: } 0.3368 \\
\text { Col: } 0.3353\end{array}$ & $\begin{array}{c}\text { Row: } \\
0.2415 \\
\text { Col: } 0.2686\end{array}$ & $\begin{array}{c}\text { Row: } \\
0.4102 \\
\text { Col:0.4171 }\end{array}$ \\
\hline Slant & $\begin{array}{c}\text { Row: } \\
0.9153 \\
\text { Col:0.5000 }\end{array}$ & $\begin{array}{c}\text { Row: } \\
0.7708 \\
\text { Col: } 0.2248\end{array}$ & $\begin{array}{c}\text { Row: } \\
0.3037 \\
\text { Col:0.9922 }\end{array}$ & $\begin{array}{c}\text { Row: } 0.6537 \\
\text { Col:0.7370 }\end{array}$ & $\begin{array}{c}\text { Row: } 0.4033 \\
\text { Col:0.4236 }\end{array}$ & $\begin{array}{c}\text { Row: } \\
0.6477 \\
\text { Col:0.5913 }\end{array}$ \\
\hline Kekre & $\begin{array}{c}\text { Row: } \\
0.9933 \\
\text { Col:0.8470 }\end{array}$ & $\begin{array}{c}\text { Row: } \\
0.7393 \\
\text { Col: } 0.2306\end{array}$ & $\begin{array}{c}\text { Row: } \\
0.8334 \\
\text { Col:0.9927 }\end{array}$ & $\begin{array}{c}\text { Row: } 0.2766 \\
\text { Col: } 0.8963\end{array}$ & $\begin{array}{c}\text { Row: } \\
0.9300 \\
\text { Col:0.9159 }\end{array}$ & $\begin{array}{c}\text { Row: } \\
0.2808 \\
\text { Col:0.2462 }\end{array}$ \\
\hline Haar & $\begin{array}{c}\text { Row: } \\
0.9381 \\
\text { Col:0.2251 }\end{array}$ & $\begin{array}{c}\text { Row: } \\
0.7748 \\
\text { Col:0.2226 }\end{array}$ & $\begin{array}{c}\text { Row: } \\
0.2202 \\
\text { Col:0.9923 }\end{array}$ & $\begin{array}{c}\text { Row: } 0.6153 \\
\text { Col:0.6225 }\end{array}$ & $\begin{array}{c}\text { Row: } \\
0.2963 \\
\text { Col: } 0.3150\end{array}$ & $\begin{array}{c}\text { Row: } \\
0.6205 \\
\text { Col: } 0.5891\end{array}$ \\
\hline
\end{tabular}




\begin{tabular}{|c|c|c|c|c|c|c|}
\hline & \multicolumn{4}{|c|}{ Original Image : Cartoon Row: 0.8027} & \multicolumn{2}{|c|}{ Col:0.8070 } \\
\hline $\begin{array}{c}\text { Transfo } \\
\text { rms }\end{array}$ & $\begin{array}{c}\text { Row } \\
\text { Transform }\end{array}$ & $\begin{array}{c}\text { Row } \\
\text { Transform } \\
\text { Scrambled }\end{array}$ & $\begin{array}{c}\text { Column } \\
\text { Transform }\end{array}$ & $\begin{array}{c}\text { Column } \\
\text { Transform } \\
\text { Scrambled }\end{array}$ & $\begin{array}{c}\text { Full } \\
\text { Transform }\end{array}$ & $\begin{array}{c}\text { Full } \\
\text { Transform } \\
\text { Scrambled }\end{array}$ \\
\hline Walsh & $\begin{array}{c}\text { Row: } \\
0.9951 \\
\text { Col:0.2066 }\end{array}$ & $\begin{array}{c}\text { Row: } 0.3754 \\
\text { Col:0.4798 }\end{array}$ & $\begin{array}{c}\text { Row: } 0.2734 \\
\text { Col:0.9954 }\end{array}$ & $\begin{array}{c}\text { Row: } 0.4359 \\
\text { Col:0.4656 }\end{array}$ & $\begin{array}{c}\text { Row: } \\
0.3931 \\
\text { Col:0.2410 }\end{array}$ & $\begin{array}{c}\text { Row: } \\
0.4824 \\
\text { Col:0.5344 }\end{array}$ \\
\hline Slant & $\begin{array}{c}\text { Row: } \\
0.8822 \\
\text { Col:0.4816 }\end{array}$ & $\begin{array}{c}\text { Row: } 0.8810 \\
\text { Col: } 0.2522\end{array}$ & $\begin{array}{c}\text { Row: } 0.3171 \\
\text { Col:0.9954 }\end{array}$ & $\begin{array}{c}\text { Row: } 0.6384 \\
\text { Col:0.8893 }\end{array}$ & $\begin{array}{c}\text { Row: } \\
0.3923 \\
\text { Col:0.3992 }\end{array}$ & $\begin{array}{c}\text { Row: } 0.7195 \\
\text { Col:0.6217 }\end{array}$ \\
\hline Kekre & $\begin{array}{c}\text { Row: } \\
0.9942 \\
\text { Col: } 0.7956\end{array}$ & $\begin{array}{c}\text { Row: } 0.8522 \\
\text { Col: } 0.2878\end{array}$ & $\begin{array}{c}\text { Row: } 0.7676 \\
\text { Col:0.9953 }\end{array}$ & $\begin{array}{c}\text { Row: } 0.2629 \\
\text { Col: } 0.9591\end{array}$ & $\begin{array}{c}\text { Row: } \\
0.9577 \\
\text { Col:0.9247 }\end{array}$ & $\begin{array}{c}\text { Row: } \\
0.3787 \\
\text { Col:0.3010 }\end{array}$ \\
\hline Haar & $\begin{array}{c}\text { Row: } \\
0.9252 \\
\text { Col:0.2525 }\end{array}$ & $\begin{array}{c}\text { Row: } 0.8542 \\
\text { Col:0.2626 }\end{array}$ & $\begin{array}{c}\text { Row: } 0.2592 \\
\text { Col:0.9956 }\end{array}$ & $\begin{array}{c}\text { Row: } 0.6063 \\
\text { Col:0.8189 }\end{array}$ & $\begin{array}{c}\text { Row: } \\
0.3065 \\
\text { Col: } 0.2804\end{array}$ & $\begin{array}{c}\text { Row: } \\
0.6822 \\
\text { Col:0.6449 }\end{array}$ \\
\hline
\end{tabular}

\begin{tabular}{|c|c|c|c|c|c|c|}
\hline & \multicolumn{4}{|c|}{ Original Image : Baboon Row: 0.7179} & \multicolumn{2}{|c|}{ Col:0.6935 } \\
\hline $\begin{array}{c}\text { Transfor } \\
\text { ms }\end{array}$ & $\begin{array}{c}\text { Row } \\
\text { Transform }\end{array}$ & $\begin{array}{c}\text { Row } \\
\text { Transform } \\
\text { Scrambled }\end{array}$ & $\begin{array}{l}\text { Column } \\
\text { Transform }\end{array}$ & $\begin{array}{c}\text { Column } \\
\text { Transform } \\
\text { Scrambled }\end{array}$ & $\begin{array}{c}\text { Full } \\
\text { Transform }\end{array}$ & $\begin{array}{c}\text { Full } \\
\text { Transform } \\
\text { Scrambled }\end{array}$ \\
\hline Walsh & $\begin{array}{c}\text { Row: } \\
0.9932 \\
\text { Col: } 0.2117\end{array}$ & $\begin{array}{c}\text { Row: } 0.3331 \\
\text { Col:0.3686 }\end{array}$ & $\begin{array}{c}\text { Row: } \\
0.2436 \\
\text { Col:0.9937 }\end{array}$ & $\begin{array}{c}\text { Row: } \\
0.3087 \\
\text { Col:0.3147 }\end{array}$ & $\begin{array}{c}\text { Row: } 0.2564 \\
\text { Col:0.2250 }\end{array}$ & $\begin{array}{c}\text { Row: } \\
0.3766 \\
\text { Col: } 0.4097\end{array}$ \\
\hline Slant & $\begin{array}{c}\text { Row: } \\
0.7745 \\
\text { Col:0.4015 }\end{array}$ & $\begin{array}{c}\text { Row: } 0.8865 \\
\text { Col:0.2220 }\end{array}$ & $\begin{array}{c}\text { Row: } \\
0.2910 \\
\text { Col:0.9937 }\end{array}$ & $\begin{array}{c}\text { Row: } \\
0.4912 \\
\text { Col:0.8591 }\end{array}$ & $\begin{array}{c}\text { Row: } 0.3603 \\
\text { Col:0.3813 }\end{array}$ & $\begin{array}{c}\text { Row: } \\
0.4948 \\
\text { Col:0.5261 }\end{array}$ \\
\hline Kekre & $\begin{array}{c}\text { Row: } \\
0.9875 \\
\text { Col: } 0.6756\end{array}$ & $\begin{array}{l}\text { Row: } 0.8610 \\
\text { Col: } 0.2429\end{array}$ & $\begin{array}{c}\text { Row: } \\
0.6758 \\
\text { Col:0.9934 }\end{array}$ & $\begin{array}{c}\text { Row: } \\
0.2563 \\
\text { Col:0.9601 }\end{array}$ & $\begin{array}{c}\text { Row: } 0.8523 \\
\text { Col:0.8342 }\end{array}$ & $\begin{array}{c}\text { Row: } \\
0.3000 \\
\text { Col: } 0.2667\end{array}$ \\
\hline Haar & $\begin{array}{c}\text { Row: } \\
0.8299 \\
\text { Col: } 0.1984\end{array}$ & $\begin{array}{c}\text { Row: } 0.8725 \\
\text { Col:0.2215 }\end{array}$ & $\begin{array}{c}\text { Row: } \\
0.1940 \\
\text { Col:0.9937 }\end{array}$ & $\begin{array}{c}\text { Row: } \\
0.4702 \\
\text { Col: } 0.7401\end{array}$ & $\begin{array}{c}\text { Row: } 0.2026 \\
\text { Col:0.2035 }\end{array}$ & $\begin{array}{c}\text { Row: } \\
0.4734 \\
\text { Col: } 0.4943\end{array}$ \\
\hline
\end{tabular}




\begin{tabular}{|c|c|c|c|c|c|c|}
\hline & \multicolumn{4}{|c|}{ Original Image : Lotus $\quad$ Row: $\mathbf{0 . 8 1 6 3}$} & \multicolumn{2}{|l|}{ Dol:0.8461 } \\
\hline $\begin{array}{c}\text { Transfor } \\
\text { ms }\end{array}$ & $\begin{array}{c}\text { Row } \\
\text { Transform }\end{array}$ & $\begin{array}{c}\text { Row } \\
\text { Transform } \\
\text { Scrambled }\end{array}$ & $\begin{array}{c}\text { Column } \\
\text { Transform }\end{array}$ & $\begin{array}{c}\text { Column } \\
\text { Transform } \\
\text { Scrambled }\end{array}$ & $\begin{array}{c}\text { Full } \\
\text { Transform }\end{array}$ & $\begin{array}{c}\text { Full } \\
\text { Transform } \\
\text { Scrambled }\end{array}$ \\
\hline Walsh & $\begin{array}{c}\text { Row: } \\
0.9857 \\
\text { Col:0.1934 }\end{array}$ & $\begin{array}{c}\text { Row: } 0.2906 \\
\text { Col: } 0.4174\end{array}$ & $\begin{array}{c}\text { Row: } 0.2093 \\
\text { Col:0.9885 }\end{array}$ & $\begin{array}{c}\text { Row: } 0.3509 \\
\text { Col:0.3108 }\end{array}$ & $\begin{array}{c}\text { Row: } \\
0.2333 \\
\text { Col:0.2295 }\end{array}$ & $\begin{array}{c}\text { Row: } \\
0.3844 \\
\text { Col:0.4271 }\end{array}$ \\
\hline Slant & $\begin{array}{c}\text { Row: } \\
0.8693 \\
\text { Col:0.4610 }\end{array}$ & $\begin{array}{c}\text { Row: } 0.6497 \\
\text { Col:0.2216 }\end{array}$ & $\begin{array}{c}\text { Row: } 0.3401 \\
\text { Col:0.9858 }\end{array}$ & $\begin{array}{c}\text { Row: } 0.5389 \\
\text { Col:0.5948 }\end{array}$ & $\begin{array}{c}\text { Row: } \\
0.4066 \\
\text { Col:0.4098 }\end{array}$ & $\begin{array}{c}\text { Row: } \\
0.5541 \\
\text { Col: } 0.5805\end{array}$ \\
\hline Kekre & $\begin{array}{c}\text { Row: } \\
0.9796 \\
\text { Col:0.8487 }\end{array}$ & $\begin{array}{c}\text { Row: } 0.6158 \\
\text { Col:0.2260 }\end{array}$ & $\begin{array}{c}\text { Row: } 0.8196 \\
\text { Col:0.9892 }\end{array}$ & $\begin{array}{c}\text { Row: } 0.2323 \\
\text { Col:0.7988 }\end{array}$ & $\begin{array}{c}\text { Row: } \\
0.9242 \\
\text { Col:0.8973 }\end{array}$ & $\begin{array}{c}\text { Row: } \\
0.2528 \\
\text { Col: } 0.2409\end{array}$ \\
\hline Haar & $\begin{array}{c}\text { Row: } \\
0.8871 \\
\text { Col:0.2111 }\end{array}$ & $\begin{array}{c}\text { Row: } 0.6503 \\
\text { Col:0.2331 }\end{array}$ & $\begin{array}{c}\text { Row: } 0.2210 \\
\text { Col: } 0.9847\end{array}$ & $\begin{array}{c}\text { Row: } 0.5430 \\
\text { Col: } 0.5760\end{array}$ & $\begin{array}{c}\text { Row: } \\
0.2869 \\
\text { Col:0.2730 }\end{array}$ & $\begin{array}{c}\text { Row: } \\
0.5479 \\
\text { Col: } 0.5605\end{array}$ \\
\hline
\end{tabular}

The Figure 8 - Figure 11 shows the blockwise cummulative energy in the transform coefficients after applying row transform, column transform and full transform. Energy in the coefficients is calculated by dividing the image in to blocks. The first block is of size $2 \times 2$, the second block considered is $4 \times 4$ which includes the first block and an increase in the block size by 2 and so on.

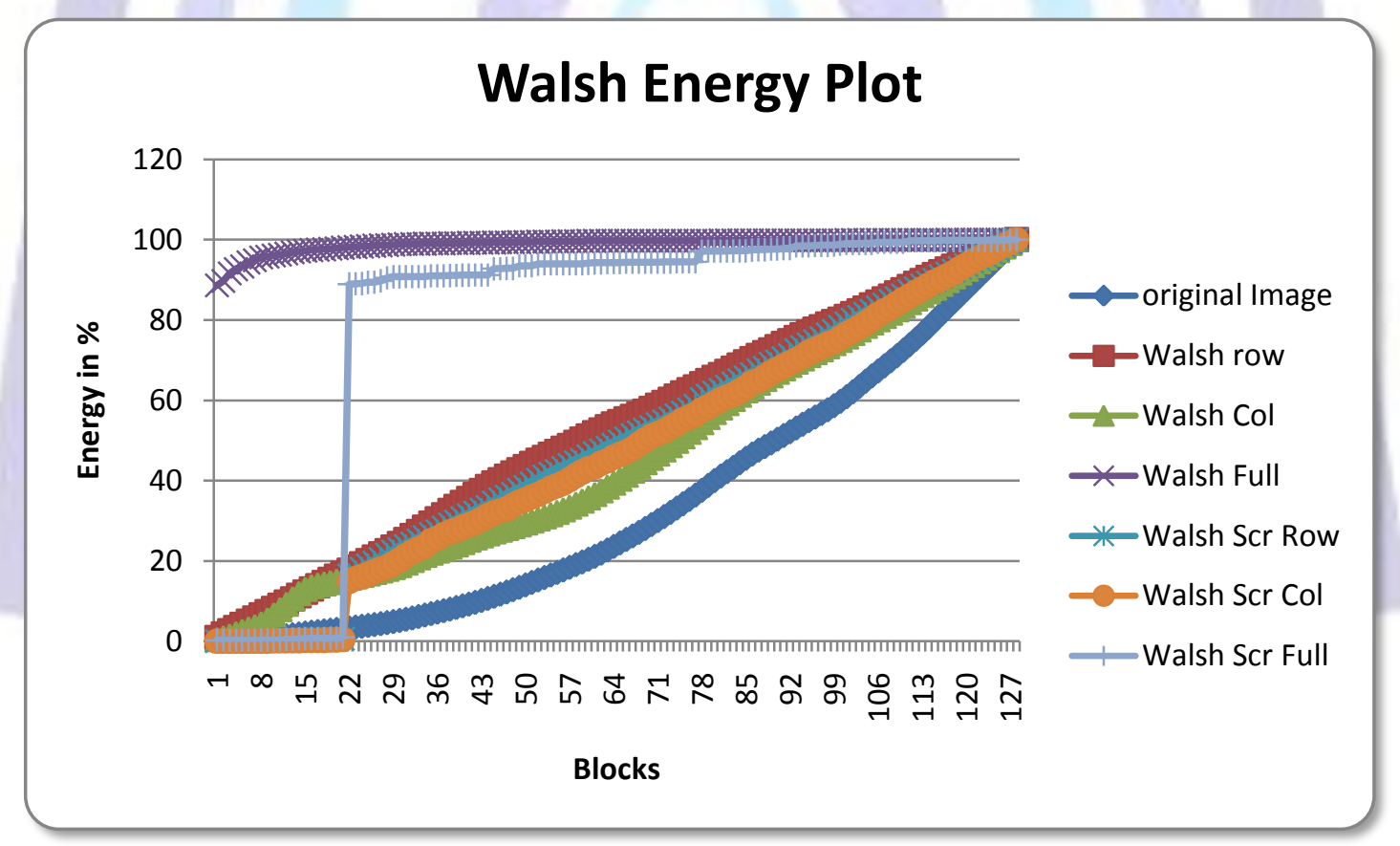

FIG 8: Block wise Energy obtained in original, Walsh row, Walsh column, Walsh full, Walsh row scrambled, Walsh Column Scrambled, Walsh Full scrambled 


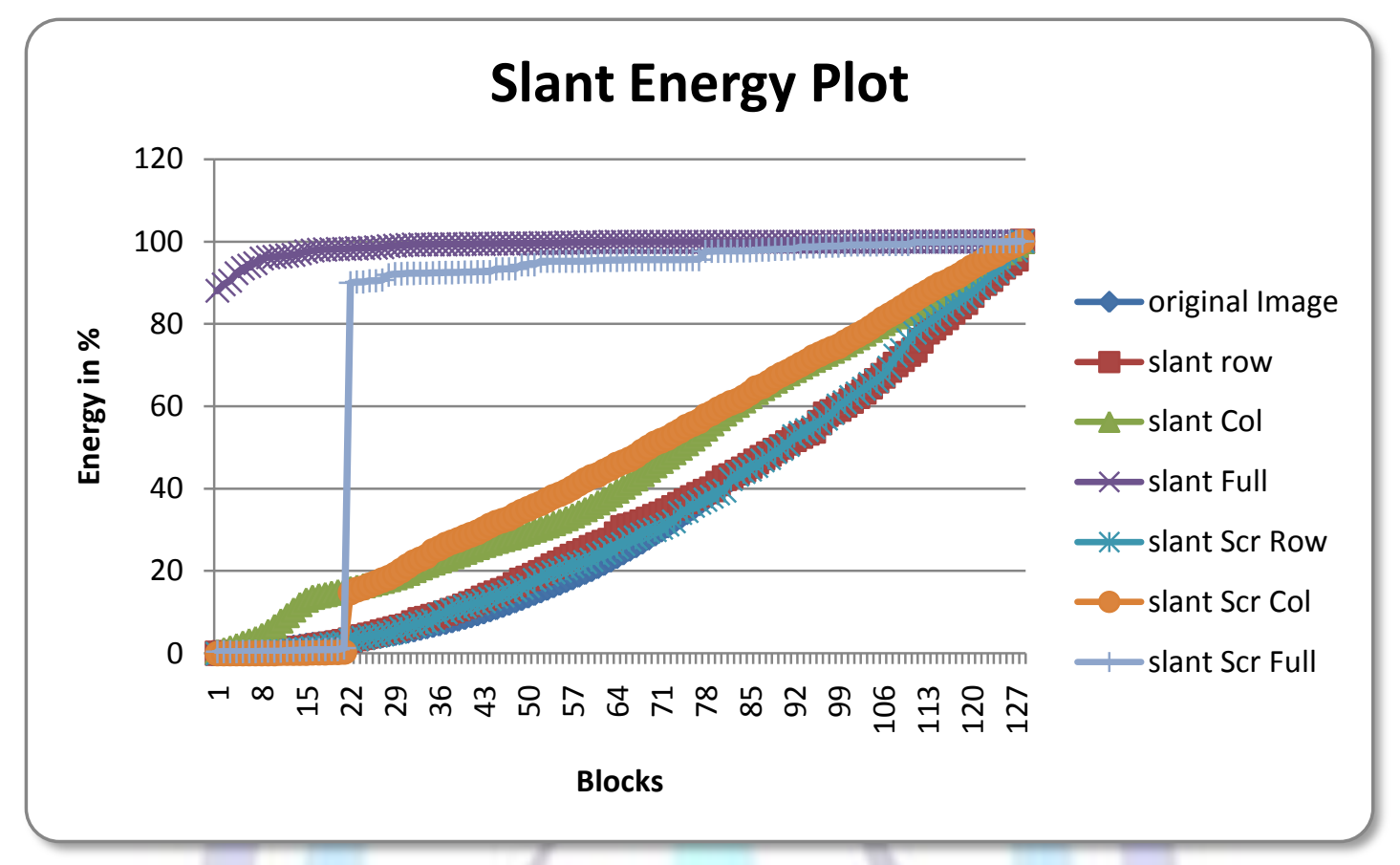

FIG 9: Block wise Energy obtained in original, Slant row, Slant column, Slant full, Slant row scrambled, Slant Column Scrambled, Slant Full scrambled

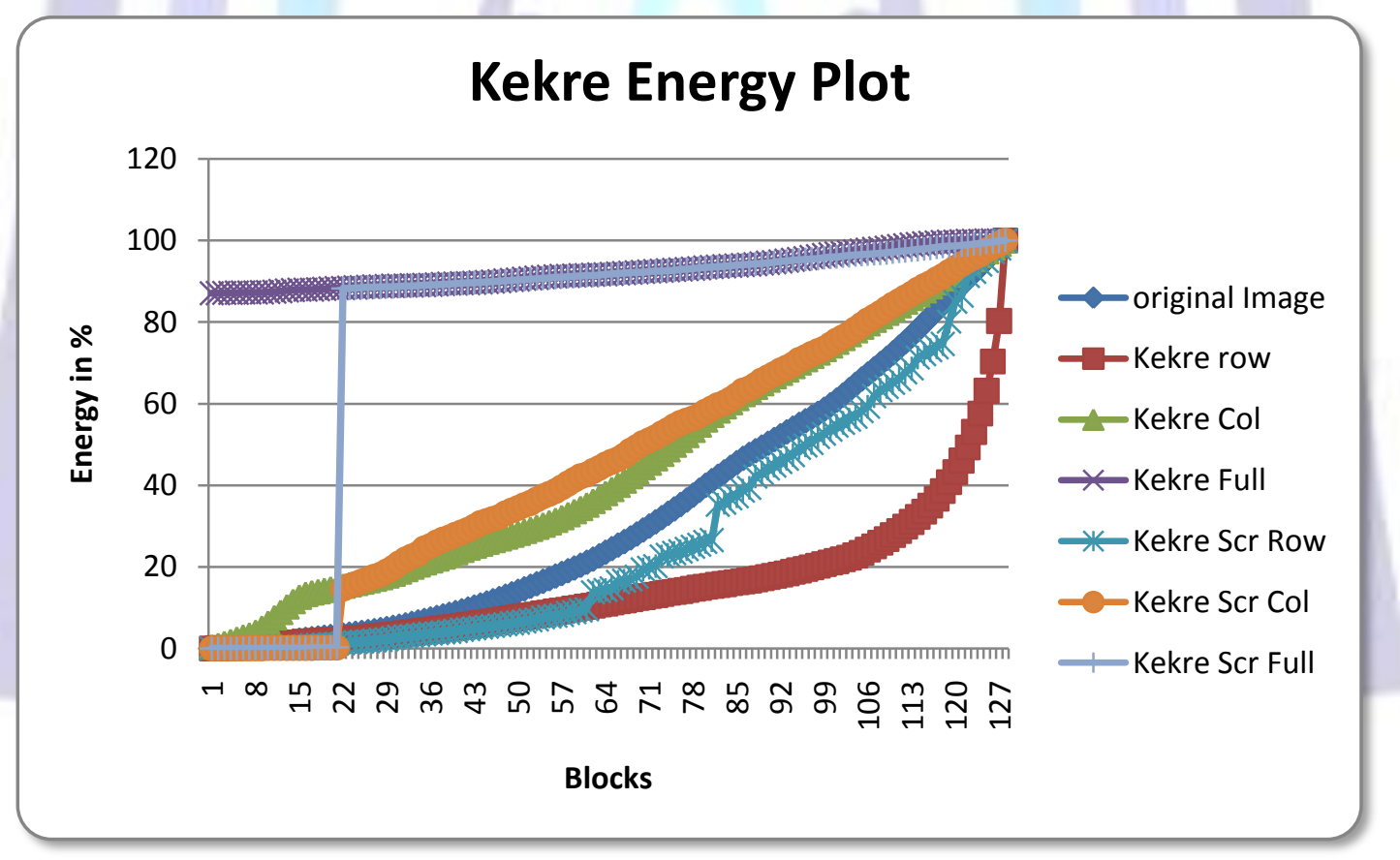

FIG 10: Block wise Energy obtained in original, kekre row, kekre column, kekre full, kekre row scrambled, kekre Column Scrambled, kekre Full scrambled 


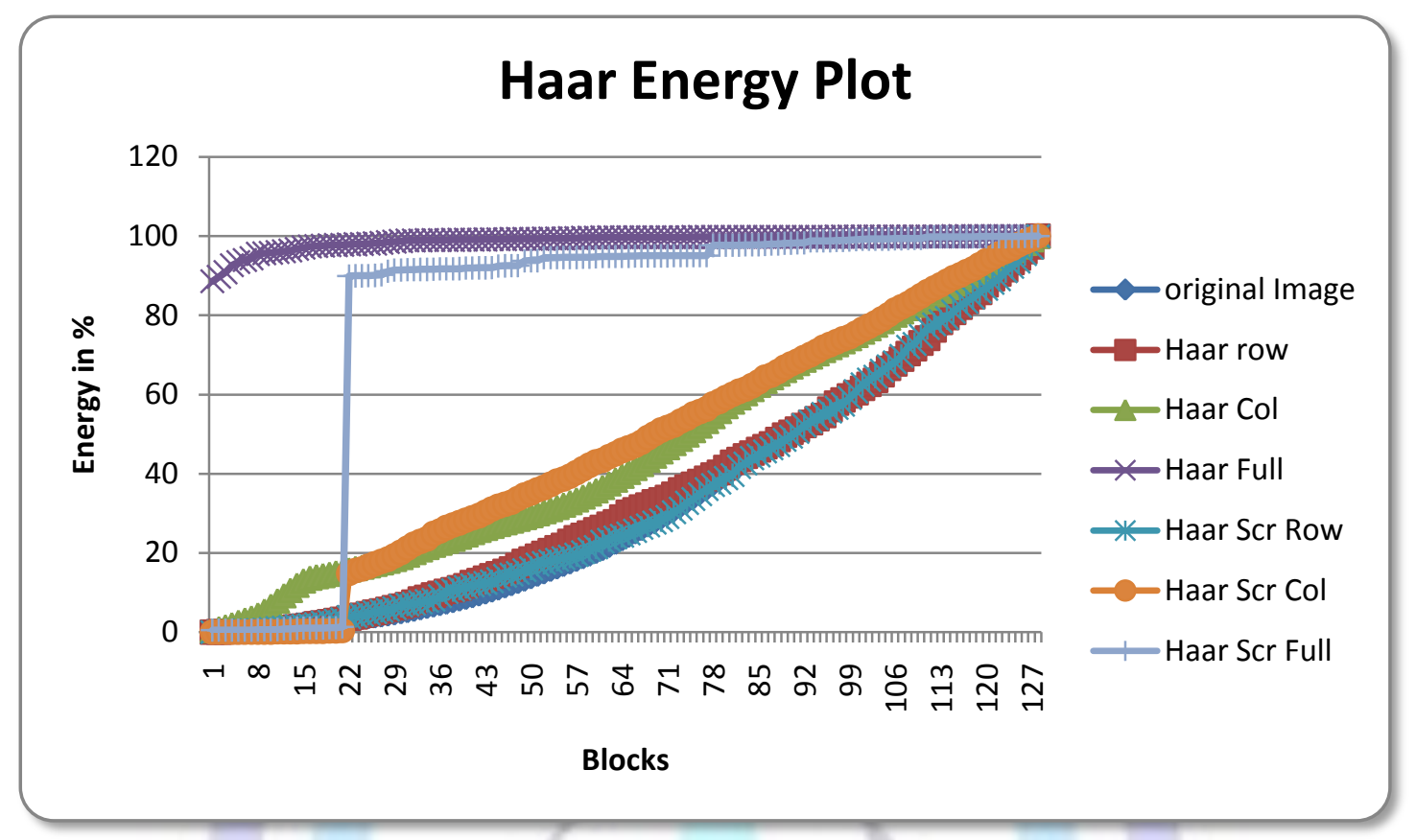

FIG 11: Block wise Energy obtained in original, Haar row, Haar column, Haar full, Haar row scrambled, Haar Column Scrambled, Haar Full scrambled

\section{CONCLUSION}

In this paper we have proposed a method for Image scrambling which is based on a combination of spatial and frequency domain. Four different Non sinusoidal transforms, Walsh, Slant ,Kekre and Haar were used. Three different types i.e Row , Column and Full Transforms of these four transforms were applied for Image scrambling , out of these four Kekre Transform gave the best result. To some extent Slant row transform also gave good result for Lena ,pepper and cartoon and Haar row transform for pepper image. Energy distribution were found similar in all the four non sinusoidal transforms with Original image, Row , column transformed image and Row scrambled image having a linear increase, whereas energy was found to be in the range of $80 \%$ in Full Transformed image in the initial blocks and then a small increase till the last block in the image. In the Full transform scrambled image, energy was very less approx to 0 and then a sudden increase in the energy after $22^{\text {nd }}$ block of the image. This energy distribution in the scrambled image shows a common property for all the full transforms which can be very useful to check whether the image is scrambled. Thus we can conclude that we have successfully presented a scrambling technique which is combining both spatial as well as frequency domain and used average correlation between rows and columns as a measure for experimental analysis along with energy distribution.

\section{REFERENCES}

[1]. Zhu, Guiliang, Weiping Wang, Xiaoqiang Zhang, and Mengmeng Wang. "Digital image encryption algorithm based on pixels." In Intelligent Computing and Intelligent Systems (ICIS), 2010 IEEE International Conference on, vol. 1, pp. 769-772. IEEE, 2010.

[2]. Ravishankar, K. C., and M. G. Venkateshmurthy. "Region based selective image encryption." In Computing \& Informatics, 2006. ICOCI'06. International Conference on, pp. 1-6. IEEE, 2006.

[3]. Samanta, Sabyasachi, Saurabh Dutta, and Goutam Sanyal. "An enhancement of security of image using permutation of RGB-components." In Electronics Computer Technology (ICECT), 2011 3rd International Conference on, vol. 2, pp. 404-408. IEEE, 2011.

[4]. $\quad$ Li, Shujun, and Xuan Zheng. "On the security of an image encryption method." In Image Processing. 2002. Proceedings. 2002 International Conference on, vol. 2, pp. II-925. IEEE, 2002.

[5]. Kamali, Seyed Hossein, Reza Shakerian, Maysam Hedayati, and Mohsen Rahmani. "A new modified version of Advanced Encryption Standard based algorithm for image encryption." In Electronics and Information Engineering (ICEIE), 2010 International Conference On, vol. 1, pp. V1-141. IEEE, 2010.

[6]. Sethi, Nidhi, and Deepika Sharma. "A new cryptology approach for image encryption." In Parallel Distributed and Grid Computing (PDGC), 2012 2nd IEEE International Conference on, pp. 905-908. IEEE, 2012.

[7]. Dey, Somdip. "SD-AEI: An advanced encryption technique for images." InDigital Information Processing and Communications (ICDIPC), 2012 Second International Conference on, pp. 68-73. IEEE, 2012 
[8]. Feng, Yong, and Xinghuo Yu. "A novel symmetric image encryption approach based on an invertible twodimensional map." In Industrial Electronics, 2009. IECON'09. 35th Annual Conference of IEEE, pp. 1973-1978. IEEE, 2009.

[9]. Zhou, Shihua, Qiang Zhang, and Xiaopeng Wei. "Image Encryption Algorithm Based on DNA Sequences for the Big Image." In Multimedia Information Networking and Security (MINES), 2010 International Conference on, pp. 884-888. IEEE, 2010.

[10]. Ahmed, Fawad, M. Y. Siyal, and Vali Uddin Abbas. "A perceptually scalable and jpeg compression tolerant image encryption scheme." In Image and Video Technology (PSIVT), 2010 Fourth Pacific-Rim Symposium on, pp. 232 238. IEEE, 2010.

[11]. H. B. Kekre, Kavita B. Patil, "Walsh Transform over color distribution of Rows and Columns of Images for CBIR", International Conference on Content Based Image Retrieval (ICCBIR) PES Institute of Technology, Bangalore on 16-18 July 2008.

[12]. W. K. Pratt, W. H. Chen, L. R. Welch, "Slant Transform Image Coding.", IEEE Trans. Comm. COM-22, pp.: 10751093, August 1974.

[13]. Dr.H.B.Kekre, Sudeep D. Thepade, Archana Athawale, Anant Shah, Prathamesh Verlekar and Suraj Shirke, "Energy Compaction and Image Splitting for Image Retrieval using Kekre Transform over Row and Column Feature Vectors", IJCSNS International Journal of Computer Science and Network Security, VOL.10 No.1, January 2010.

[14]. Dr. H.B.Kekre, Sudeep D. Thepade, Akshaya Maloo, "Query by Image Content using Color-Texture Features Extracted from Haar Wavelet Pyramid", IJCA Special Issue on "Computer Aided Soft Computing Techniques for Imaging and Biomedical Applications"(CASCT), 52-60, August, 2010.

[15]. P. Premaratne \& M. Premaratne, "Key-based scrambling for secure image communication," in Emerging Intelligent Computing Technology and Applications, P. P. Gupta, D. Huang, P. Premaratne \& X. Zhang, Ed. Berlin: Springer, 2012, pp.259-263.

\section{BIOGRAPHY}

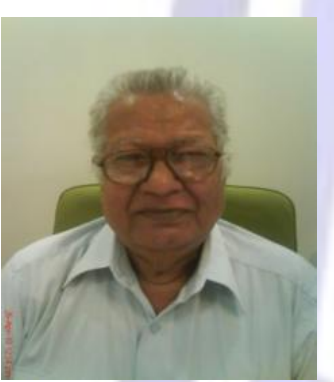

Dr. H. B. Kekre has received B.E (Hons.) in Telecomm Engineering from Jabalpur University in 1958, M.Tech (Industrial Electronics) from IIT Bombay in 1960, M.S.Engg. (Electrical Engg.) from University of Ottawa, Canada in 1965 and Ph.D. (System Identification) from IIT Bombayin 1970. He has worked as Faculty of Electrical Engg. and then HOD Computer Science and Engg. at IIT Bombay. After serving IIT for 35 years he retired in 1995. After retirement from IIT, for 13 years he was working as a professor and head in the Department of Computer Engg. and Vice Principal at Thadomal Shahani Engineering. College, Mumbai. Now he is Senior Professor at MPSTME, SVKM"s NMIMS University. He has guided $17 \mathrm{Ph} . \mathrm{Ds}$, more than 100 M.E./M.Tech and several B.E./ B.Tech projects, while in IIT and TSEC. His areas of interest are Digital Signal processing, Image Processing and Computer Networking. He has more than 450 papers in National / International Journals and Conferences to his credit. He was Senior Member of IEEE. Presently $\mathrm{He}$ is Fellow of IETE, Life Member of ISTE and Senior Member of International Association of Computer Science and Information Technology (IACSIT). Recently fifteen students working under his guidance have received best paper awards. Currently eight research scholars working under his guidance have been awarded Ph. D. by NMIMS (Deemed to be University). At present eight research scholars are pursuing Ph.D. program under his guidance.

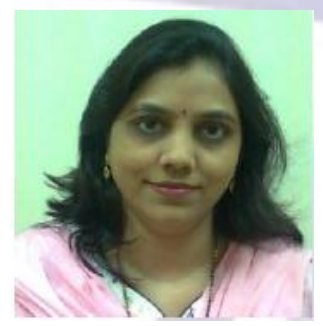

Dr. Tanuja K. Sarode has received M.E. (Computer Engineering) degree from Mumbai University in 2004, Ph.D. from Mukesh Patel School of Technology, Management and Engg. SVKM"s NMIMS University, Vile-Parle (W), Mumbai, INDIA. She has more than 11 years of experience in teaching. Currently working as Assistant Professor in Dept. of Computer Engineering at Thadomal Shahani Engineering College, Mumbai. She is member of International Association of Engineers (IAENG) and International Association of Computer Science and Information Technology (IACSIT). Her areas of interest are Image Processing, Signal Processing and Computer Graphics. She has 150 papers in National /International Conferences/journal to her credit.

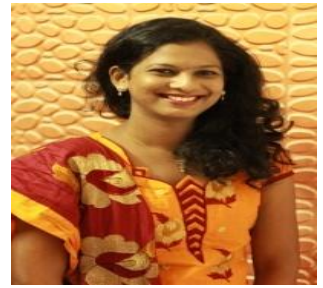

Ms. Pallavi N.Halarnkar has received M.E. (Computer Engineering) degree from Mumbai University in 2010, currently persuing her Ph.D. from Mukesh Patel School of Technology, Management and Engg. SVKM"s NMIMS University, Vile-Parle (W), Mumbai, INDIA. She has more than 8 years of experience in teaching. Currently working as Assistant Professor in Dept. of Computer Engineering at Mukesh Patel School of Technology, Management and Engg. SVKM"s NMIMS University, Vile-Parle (W), Mumbai. She has 20 papers in National /International Conferences/journal to her credit. 